\title{
An Assessment of the Contribution of Municipal Solid Waste Dump Sites Fire to Atmospheric Pollution
}

\author{
Akpofure Rim-Rukeh \\ Department of Environmental Science, Federal University of Petroleum Resources, \\ Effurun, Nigeria \\ Email: arimrukeh@yahoo.co.uk
}

Received 3 July 2014; revised 31 July 2014; accepted 7 August 2014

Copyright (C) 2014 by author and Scientific Research Publishing Inc. This work is licensed under the Creative Commons Attribution International License (CC BY). http://creativecommons.org/licenses/by/4.0/

c) (i) Open Access

\begin{abstract}
Municipal solid waste open dump site operation is an important element of waste management in Nigeria, both today and in the future. Dump site fires are common occurrences in the study area. The contribution of municipal solid waste dump site fires to atmospheric pollution in the Niger Delta, Nigeria has been assessed experimentally. Five (5) municipal solid waste dump sites where fire incidence is a frequent and regular occurrence were chosen for the study. At each of the identified municipal solid waste dump site, eight (8) air quality monitoring parameters, suspended particulate matter $\left(\mathrm{SPM}_{10}\right)$, nitrogen dioxide $\left(\mathrm{NO}_{2}\right)$, carbon dioxide $\left(\mathrm{CO}_{2}\right)$, carbon monoxide (CO), sulphur dioxide $\left(\mathrm{SO}_{2}\right)$, methane $\left(\mathrm{CH}_{4}\right)$, ammonia $\left(\mathrm{NH}_{3}\right)$ and Hydrogen sulphide $\left(\mathrm{H}_{2} \mathrm{~S}\right)$ were determined using a series of hand held air quality monitoring equipment. Results indicate the levels of SPM ranged between 773 and $801 \mu \mathrm{g} / \mathrm{m}^{3}$ and the levels of CO ranged between 133.7 and 141.6 ppm. The levels of $\mathrm{CO}_{2}$ ranged between $401 \mathrm{ppm}$ and $404.5 \mathrm{ppm}$ while that of $\mathrm{NO}_{2}$ ranged between $21.0 \mathrm{ppm}$ and $27.3 \mathrm{ppm}$. The levels of $\mathrm{SO}_{2}$ ranged between $27.7 \mathrm{ppm}$ and $37.1 \mathrm{ppm}$ while that of $\mathrm{NH}_{3}$ ranged from 14.7 to $19.5 \mathrm{ppm}$. The levels of methane in the study area ranged between 2310 ppm and 2771 ppm and within the vicinity of dump site fires $\mathrm{H}_{2} \mathrm{~S}$ concentration ranges from 3.4 to 7.7 ppm. Levels of SPM, CO, $\mathrm{CO}_{2}$, and $\mathrm{CH}_{4}$ within the vicinity of the dump site fires were above regulatory limits. Dump site fires in the study area could threaten the health of anyone especially the dump site workers that are regularly exposed to the thick smoke and can be implicated in climate change debate. There is a need to develop better practices with regard to municipal solid waste open dump site operation and emission control.
\end{abstract}

\section{Keywords}

Dump Site Fire, Landfills, Air Quality, Solid Waste, Methane, Climate Change 


\section{Introduction}

The quality of air we breath continues to receive a great deal of interest worldwide due to its negative impacts on human health and welfare. Several studies have reported significant correlations between air quality and certain diseases such as, shortness of breath, sore throat, chest pain, nausea, asthma, bronchitis and lung cancer [1]-[4]. Extreme effects of air pollution include high blood pressure and cardiovascular problems [5] [6]. Correlations between air quality and increased morbidity and mortality rates have also been reported [7] [8]. The World Health Organization states that 2.4 million people die each year from causes directly attributable to air pollution [9]. Epidemiological studies suggest that more than 500,000 Americans die each year from cardiopulmonary disease linked to breathing fine particle matter [10]. Another study has shown a strong correlation between pneumonia related deaths and air pollution from motor vehicles in UK [11]. In addition, air pollution is known to cause injuries to animals, forests and vegetation, and aquatic ecosystems. Its impacts on metals, structures, leather, rubber, and fabrics include cracks, soiling, deterioration, and erosion [12].

Sources of air pollution in our environment are many and varied. However, they may be of natural or anthropogenic (man-made) sources. Natural events that pollute the air include forest fires, volcanic eruptions, wind erosion, pollen dispersal, evaporation of organic compounds and natural radioactivity. Anthropogenic sources include the combustion of gasoline and other hydrocarbon fuels in automobiles, trucks, and jet airplanes, burning of fossil fuels (oil and coal) in generating stations, factories, office buildings, and homes and by the incineration of garbage (landfill fires). Every industrial process exhibits its own pattern of air pollution. Petroleum refineries are responsible for extensive hydrocarbon and particulate pollution. Iron and steel mills, metal smelters, pulp and paper mills, chemical plants, cement and asphalt plants-all discharge vast amounts of various particulates. Uninsulated high-voltage power lines ionize the adjacent air, forming ozone and other hazardous pollutants. Airborne pollutants from other sources include insecticides, herbicides, radioactive fallout, and dust from fertilizers, mining operations, and livestock feedlots.

Pollution arising from fires in landfills though very common yet have not generally receive substantial academic and media attention [13]. The complexity of landfills is increasing and there are many aspects which may affect emissions to air which are poorly documented today [14]. Emissions from Landfills can be controversial in and of themselves. Homeowners and business owners tend not to support the siting and development of landfills in their neighborhoods due to perceived notions about noxious fumes, health and environmental effects, and adverse influences on property values.

Landfill fires threaten the environment through toxic pollutants emitted into the air, water, and soil. Landfill emissions are the result of the decomposition of organic materials in the landfill (including yard waste, household waste, food waste, and paper). Because of the nature of the construction of landfills, this decomposition is anaerobic [15] and results in the production of large quantities of methane (which is highly flammable) and carbon dioxide. In fact, landfills are the largest source of methane emissions in the United States, accounting for 35 percent of methane emissions in 1999 [16]. Municipal Solid Waste (MSW) landfills generate about 93\% of U.S. landfill emissions; industrial landfills account for the remaining emissions [16]. In addition, Landfill fires cause release of toxic organic compounds into atmosphere [17]. $\mathrm{L}$ and fill fires as a major sources of dioxins have also been reported [18]. Accidental fires at landfills and the uncontrolled burning of residential waste are considered the largest sources of dioxin emissions in the United States [19]. Dioxins are also naturally occurring and are present throughout the environment. However, exposure to high levels of dioxins has been linked to cancer, liver damage, skin rashes, and reproductive and developmental disorders [20]. Smoke can still aggravate existing respiratory conditions and reduce visibility around the landfill [21].

Although open waste dump fires are widespread in Nigeria, there appears to be little research undertaken on them. Landfill fires can cause problems for operators and the fire service, and nuisance for local residents and there may be potential health risks involved. If open waste dump sites fire is ignored, or undiscovered, the fire can become large and dangerous. Assessing air quality within the vincity of open dump sites fire will help to anticipate the impacts on the concentration of greenhouse gases into the atmosphere that could contribute to climate change on one hand and examine its implication on dump site workers and recycleable waste pickers on the other hand.

\section{Materials and Methods}

\subsection{Study Area}

The study area is the Niger Delta which is located within Latitude $5^{\circ} 45^{\prime}-6^{\circ} 35^{\prime}$ and longitude $4^{\circ} 50^{\prime}-5^{\circ} 15^{\prime}$ in the 
central part of Southern Nigeria. The area has a land mass covering some 70,000 square kilometers which accounts for about 8 percent of Nigeria's land mass [22]. The area is densely populated with about 31 million people comprising of more than 40 ethnic groups including the Bini, Efik, Ibibio, Igbo, Annang, Oron, Ijaw, Itsekiri, Isoko, Urhobo, Ukwani, and Kalabari, are among the inhabitants in the Niger Delta, speaking about 250 different dialects. Geopolitically, the area comprises of all oil producing states of Abia, Akwa-Ibom, Bayelsa, Cross River, Delta, Edo, Imo, Ondo and Rivers (Figure 1).

The geology of the area is characterized by a vast flood plain built up by accumulation of sedimentary deposits washed down the Niger and Benue Rivers. The geology of the Niger Delta area has been extensively studied [23] [24]. The area is criss-crossed with numerous rivers, streams, tributaries, creeks and creeklets. The vegetation of the area is characterized by the presence of 1) sandy coastal, ridge barriers, brackish or saline mangrove forest; 2) fresh water swamp forest and 3) tropical rain forest. The area is the largest wetland in West Africa and one of the largest mangrove forests in the world [25].

Previous study [26] of the meteorology of the area reveals the average atmospheric temperature to be $25.5^{\circ} \mathrm{C}$ in the rainy season and $30^{\circ} \mathrm{C}$ in the dry season. The daily relative humidity values range from 55.5 percent in the dry season to 96.0 percent in the rainy season. Rainfall in the area averages $2500 \mathrm{~mm}$ annually. The rainfall pattern shows two identifiable seasons; the rainy season (April to October) and the relatively short dry season (November to March).

The Niger Delta area is the home of the petroleum industry in Nigeria with distribution of oil fields. It is estimated that Nigeria earns over 90 percent of its foreign exchange and over 80 percent of government revenues from the petroleum [27]. Nigeria flares 17.2 billion $\mathrm{m}^{3}$ of natural gas per year in conjunction with the exploration of crude oil in the Niger Delta [28].

\subsection{Current Solid Waste Management Practice in the Study Area}

Urban solid waste management refers to the collection, transfer, treatment, recycling, resource recovery, and disposal of solid waste generated in urban areas. It encompasses: refuse storage and collection, street and drain cleaning, solid waste transfer and transport, solid waste disposal, and resource recovery. It also involves vehicle maintenance repair, financial management, administrative activities such as routing, scheduling and record keeping; staff management and development and strategic urban solid waste management planning [29].

The disposal of municipal solid waste in the study area is presently a serious problem and will become increasingly serious as the options for disposal become more limited and the amount of such waste generated becomes greater. The current disposal practice in the area is the use of unsanitary dump sites (usually borrowed pits from which sand was mined for road construction). Unsanitary dumpsites are areas where wastes are disposed off without proper controls, including regular application of cover, controlled access to the site and other environmental controls.

In the study area, urban solid wastes are dispose off at the open dump sites and buried in a careless and unplanned way through the support of waste contractors that evacuates waste generated from the city centre and dispose same in a dump site. Composition of waste generated in the study area include; Garbage (41\%), paper and plastics (35\%), scrap metal and glass (15\%), construction waste (4\%), sludge (3\%) and expired chemical wastes and drugs (2\%) [30].

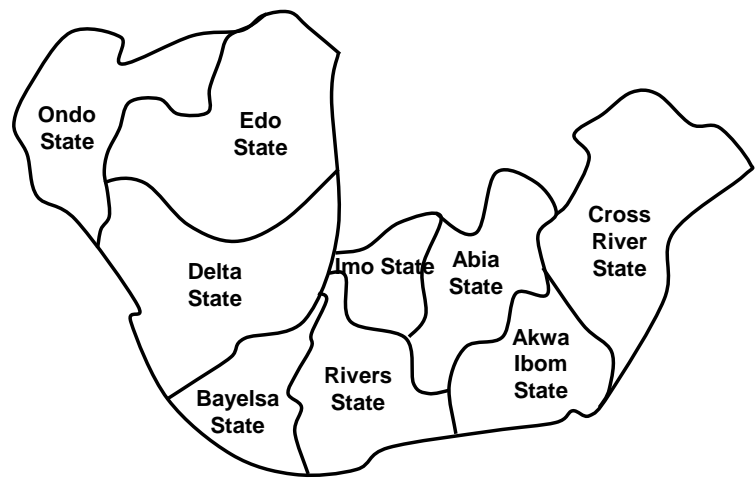

Figure 1. Geopolitical map of the Niger Delta area. 


\subsection{Methodology}

\subsubsection{Sampling Sites}

Five (5) municipal solid waste dump sites where fire incidence is a frequent and regular occurrence were chosen for the study (Table 1). Positioning at each dump site during the data gathering was achieved with the aid of a hand held Garmin Global Positioning System (GPS) V, (model CZ 99052-20).

\subsubsection{Sampling Procedures}

At each of the identified municipal solid waste dump site, eight (8) air quality monitoring parameters; suspended particulate matter $\left(\mathrm{SPM}_{10}\right)$, nitrogen dioxide $\left(\mathrm{NO}_{2}\right)$, carbon dioxide $\left(\mathrm{CO}_{2}\right)$, carbon monoxide $(\mathrm{CO})$, sulphur dioxide $\left(\mathrm{SO}_{2}\right)$, methane $\left(\mathrm{CH}_{4}\right)$, ammonia $\left(\mathrm{NH}_{3}\right)$ and Hydrogen sulphide $\left(\mathrm{H}_{2} \mathrm{~S}\right)$ were determined using a series of hand held air quality monitoring equipment. The GT-331 VI.04 A Met One Instrument, Inc. Aerosol Mass Monitor Model GT-331 was used in determination of suspended particulate matter (SPM). The monitor uses light scatter to measure individual particles instead of clouds like other monitors. The particle information is then grouped into size ranges and converted to mass concentration over 4 minutes at a flow rate of $2.83 \mathrm{~L} / \mathrm{min}$ into measuring ranges of: $<1$ micron, $\mathrm{SPM}_{10}$ mass concentration. Levels of $\mathrm{H}_{2} \mathrm{~S}, \mathrm{NH}_{3}, \mathrm{CO}, \mathrm{CO}_{2}, \mathrm{SO}_{2}, \mathrm{CH}_{4}$ and $\mathrm{NO}_{2}$ were measured using Industrial Scientific Corporation ITX Multi-Gas monitors. Measurements were done by holding the sensor to a height of about two meters in the direction of the prevailing wind and readings recorded at stability. The study was carried during the dry season within the month of December, 2013.

\section{Results and Discussion}

\subsection{Characteristics of Dump Site Fires}

At the time of visiting each of the identified municpal dump site, one common observation was the presence of dump site fire. Dump sites fires have been categorise into two, surface and underground fires [21]. Surface fires involve recently buried or uncompacted refuse, situated on or close to the dump site surface in the aerobic decomposition layer, generally 1 to $4 \mathrm{~m}$ in depth [31]. Underground fires in dump site occur deep below the dump site surface and involve materials that are months or years old [31]. These fires are generally more difficult to extinguish than surface fires.

The observed dump site fire in each of the identified municpal dump site have characterises that shows the presence of surface fire as have been similarly observed and reported [21]. Observed characteristics include: generally burning at relatively low temperatures and the emission of dense black smoke which shows the products of incomplete combustion, continous presence of fire which shows presence of undetected smoldering materials into the dump site, observation of hot load fires caused by the disposal of refuse that is still burning on arrival to the dump site (e.g., cleared brush), fires spreading into nearby framlands and building, fires may be caused by human error on the part of the dump site operators or users. Dump site workers and users can cause fires through careless smoking on the dump site, which can ignite waste or methane gas. Spontaneous combustion of materials in the dump site was also observed. Deliberate fires, which are used by the dump site operator to reduce the volume of waste. Landfills contain refuse such as dry garden waste, grass, leaves, and branches. Sometimes these materials are deliberately set on fire to reduce refuse volumes, reduce operating costs, and increase a dump site's operating life.

Table 1. Description of open dump site in study area.

\begin{tabular}{|c|c|c|c|c|c|}
\hline \multirow{2}{*}{$\mathbf{S} / \mathbf{N}$} & \multicolumn{2}{|c|}{ Coordinates } & \multirow{2}{*}{ Local government area/state } & \multirow{2}{*}{ Description of dump site location } & \multirow{2}{*}{$\begin{array}{l}\text { Identification code } \\
\text { of the dump sites }\end{array}$} \\
\hline & Northing & Easting & & & \\
\hline 1 & $5^{\circ} 33^{\prime} 0^{\prime \prime}$ & $5^{\circ} 47^{\prime} 0^{\prime \prime}$ & Uvwie /Delta & $\begin{array}{l}\text { Effurun dump site is located along New } \\
\text { NPA Express Road by Niger Cat Junction }\end{array}$ & DEL 1 \\
\hline 2 & $6^{\circ} 19^{\prime 2} 23^{\prime \prime}$ & $5^{\circ} 36^{\prime \prime} 38^{\prime \prime}$ & Oredo/Edo & Benin dump site is located along Benin-Asaba Bye Pass & EDO 1 \\
\hline 3 & $4^{\circ} 55^{\prime} 39^{\prime \prime}$ & $6^{\circ} 15^{\prime} 41^{\prime \prime}$ & Yenagoa/Bayelsa & $\begin{array}{l}\text { Yenagoa dump site is located } \\
\text { along Amasomma-Yenagoa Road }\end{array}$ & BAY 1 \\
\hline 4. & $4^{\circ} 45^{\prime} 23^{\prime \prime}$ & $6^{\circ} 50^{\prime} 17^{\prime \prime}$ & Obio-Akpor/Rivers & $\begin{array}{l}\text { Port Harcourt dump site is located at Igwruta-Eneka } \\
\text { Road, by army shooting range road }\end{array}$ & RIV 1 \\
\hline 5 & $6^{\circ} 11^{\prime} 52.13^{\prime \prime}$ & $6^{\circ} 43^{\prime} 42.41^{\prime \prime}$ & Igbozu/Delta & Asaba Dump site is located along Igbozu-Asaba Road & DEL 2 \\
\hline
\end{tabular}




\subsection{Air Quality within the Vincity of the Solid Waste Dump Site Fires}

Results of the air quality within the vincity of the solid waste dump sites fire are presented in Table 2.

Suspended particulates matter refer to particles suspended in the atmosphere, and can remain suspended for long periods where they are a key component of air pollution and smog. Particulates affect the environment as it contributes to greenhouse gases, and affects human health as they can they easily reach the deepest recesses of the lungs leading to respiratory ailments according to the US Environmental Protection Agency [2]. The levels of suspended particulates matter in the study area ranged between 773 and $801 \mu \mathrm{g} / \mathrm{m}^{3}$ which shows that the particulates present in the atmosphere were more than 3 times the regulatory limit of $250 \mu \mathrm{g} / \mathrm{m}^{3}$ [32]. High values of SPM may be attributed to huge oily smoke billowing from the sites as may have similarly reported [21]. Smoke from dump sites fire generally contains particulate matter (the products of incomplete combustion of the fuel source), which can aggravate pre-existing pulmonary conditions or cause respiratory distress. Based on the above readings, this study expresses grave concern for the impact of the particulates on human health especially the sump site workers as the readings are well above the acceptable standard of $250 \mu \mathrm{g} / \mathrm{m}^{3} / 24 \mathrm{hr}$.

Carbon monoxide (CO) is colourless, odourless, and tasteless, but highly toxic gas. It combines with haemoglobin to produce carboxyhaemoglobin, which usurps the space in hemoglobin that normally carries oxygen, but is ineffective for delivering oxygen to bodily tissues. Concentrations as low as 667 ppm may cause up to $50 \%$ of the body's hemoglobin to convert to carboxyhemoglobin [7]. A level of 50\% carboxyhemoglobin may result in seizure, coma, and fatality. In the United States, the NIOSH limits long-term workplace exposure levels above 50 ppm. Within short time scales, carbon monoxide absorption is cumulative, since the half-life is about $5 \mathrm{~h}$ in fresh air. The levels of CO in the study area ranged between 133.7 and 141.6 ppm which shows that CO concentration present in the atmosphere were more than 14 times the regulatory limit of 10 ppm [32] [34]. Levels between 10 and 100 ppm may be an indication of a fire but active combustion is not present [35]. However, obtained values were below elevated levels of CO in excess of 1000 ppm reported for landfills fires in United States indicating underground landfill fire [21].

Carbon dioxide $\left(\mathrm{CO}_{2}\right)$ odourless, colourless gas, It is an important long-lived trace gas in Earth's atmosphere currently constituting about $0.04 \%$ (400 parts per million) of the atmosphere on a molar basis. Despite its relatively small overall concentration, $\mathrm{CO}_{2}$ is a potent greenhouse gas and plays a vital role in regulating Earth's surface temperature. Carbon dioxide, which comprises $40 \%$ to $60 \%$ of landfill gas, may pose specific asphyxiation hazard concerns. Because it is denser than air, carbon dioxide that has escaped from a landfill and collected in a confined space, such as a basement or an underground utility corridor, may remain in the area for hours or days after the area has been opened to the air (e.g., after a manhole cover has been removed or a basement door opened). Carbon dioxide concentrations of $10 \%$ or more can cause unconsciousness or death. Lower concentrations may cause headache, sweating, rapid breathing, increased heartbeat, shortness of breath, dizziness, mental depression, visual disturbances, or shaking. The seriousness of these symptoms depends on the concentration and duration of exposure. The response to carbon dioxide inhalation varies greatly even in healthy normal individuals. The levels of $\mathrm{CO}_{2}$ in the study area ranged between $401 \mathrm{ppm}$ and $404.5 \mathrm{ppm}$ which shows that $\mathrm{CO}_{2}$ concentration present in the atmosphere were just a little above regulatory limit of 400 ppm [32]. Approximately 45\% of gas emitted from landfills is carbon dioxide and in terms of climate change it has global warming potential (GWP) of 1 [36].

Table 2. Air Quality within the vincity of the solid waste dump site fire.

\begin{tabular}{|c|c|c|c|c|c|c|}
\hline \multirow{2}{*}{ Parameters/units } & \multicolumn{5}{|c|}{ Dump site codes } & \multirow{2}{*}{ Air quality regulatory limits [32]-[34] } \\
\hline & DEL 1 & EDO 1 & BAY 1 & RIV 1 & DEL 2 & \\
\hline $\operatorname{SPM}\left(\mu \mathrm{g} / \mathrm{m}^{3}\right)$ & 778 & 790 & 801 & 773 & 792 & $250\left(\mu \mathrm{g} / \mathrm{m}^{3}\right)$ \\
\hline $\mathrm{CO}$ ppm & 133.9 & 141.0 & 133.7 & 140.2 & 141.6 & $10 \mathrm{ppm}$ \\
\hline $\mathrm{CO}_{2} \mathrm{ppm}$ & 401.7 & 404.5 & 402.3 & 401.0 & 403.6 & 397 ppm \\
\hline $\mathrm{NO}_{2} \mathrm{ppm}$ & 27.3 & 21.0 & 25.5 & 23.7 & 22.3 & $40-60 \mathrm{ppm}$ \\
\hline $\mathrm{SO}_{2} \mathrm{ppm}$ & 37.1 & 27.7 & 33.6 & 30.5 & 29.5 & 100 ppm \\
\hline $\mathrm{NH}_{3} \mathrm{ppm}$ & 19.5 & 14.7 & 16.6 & 15.8 & 15.1 & $<25$ ppm \\
\hline $\mathrm{CH}_{4} \mathrm{ppm}$ & 2310 & 2700 & 2662 & 2771 & 2660 & 1000 ppm \\
\hline $\mathrm{H}_{2} \mathrm{~S}$ ppm & 7.7 & 3.4 & 5.2 & 6.6 & 7.0 & 10 ppm \\
\hline
\end{tabular}


Nitrogen dioxide $\left(\mathrm{N}_{2} \mathrm{O}\right)$ is a reddish-brown toxic gas with a characteristic sharp, biting odour. It is toxic by inhalation and at low concentrations (4 ppm) the gas will anesthetize the nose, thus creating a potential for overexposure. There is some evidence that long-term exposure to $\mathrm{NO}_{2}$ at concentrations above $40-100 \mu \mathrm{g} / \mathrm{m}^{3}$ may decrease lung function and increase the risk of respiratory symptoms. $\mathrm{N}_{2} \mathrm{O}$ emissions in particular are environmentally relevant as it is a greenhouse gas with a global warming potential 300 times that of carbon dioxide. Of the Swedish contribution to the greenhouse effect, about $9 \%$ comes $\mathrm{N}_{2} \mathrm{O}$ emmissions from landfills [37]. The levels of $\mathrm{NO}_{2}$ in the study area ranged between $21.0 \mathrm{ppm}$ and $27.3 \mathrm{ppm}$ which is below regulatory limits of $40 \mathrm{ppm}$ [32].

Sulphur dioxide $\left(\mathrm{SO}_{2}\right)$ is a toxic gas with a pungent, irritating and rotten smell. Sulphur dioxide is a major air pollutant and has significant impacts upon human health. Inhaling sulphur dioxide is associated with increased respiratory symptoms and disease, difficulty in breathing, and premature death [7]. In addition the concentration of sulphur dioxide in the atmosphere can influence the habitat suitability for plant communities as well as animal life. Sulphur dioxide emissions are a precursor to acid rain and atmospheric particulates. The levels of $\mathrm{SO}_{2}$ in the study area ranged between $27.7 \mathrm{ppm}$ and $37.1 \mathrm{ppm}$ which is below regulatory limits of $100 \mathrm{ppm}$ [32]. The observed values are similar to those found at many other urban and rural locations in the UK [38].

Ammonia $\left(\mathrm{NH}_{3}\right)$ is a colourless landfill gas that is produced by the decomposition of organic matter in the landfill. People are exposed daily to low levels of ammonia in the environment from the natural breakdown of manure and dead plants and animals. In small concentrations the gas is detectable by its sharp smell. In high concentrations the gas is an immediate hazard to life. Ammonia is flammable with is lower explosive limits of $15 \%$ and its upper explosive limit is $28 \%$ and it can pose as an explosion hazard. Within the vincity of dump site fires ammonia concentration ranges from 14.7 to $19.5 \mathrm{ppm}$. Reported readings are below regulatory of $25 \mathrm{ppm}$ [33]. The odour threshold for ammonia is between 28,000 and 50,000 ppb [33]. Landfill gas has been reported to contain between $1,000,000$ and $10,000,000 \mathrm{ppb}$ of ammonia, or $0.1 \%$ to $1 \%$ ammonia by volume [33].

Methane is an odourless gas and is lighter than air. Because methane is lighter than air, it tends to rise and accumulate near the higher, stagnant parts of enclosed buildings and tightly closed manure storage pits. Methane $\left(\mathrm{CH}_{4}\right)$ is a major greenhouse gas. It is produced during anaerobic decomposition of manure and accumulates around manure storage areas. Methane emissions from manure depend on the way manure is managed (liquid manure systems produce more methane than solid manure systems) and environmental factors such as temperature and moisture (warmer temperatures and moist conditions will produce greater amounts of methane).

Methane can displace oxygen in confined areas, resulting in an oxygen-deficient atmosphere. Methane can explode at concentrations of 50,000 ppm or more (a level of 5 per cent). Methane is the constituent of landfill gas that is likely to pose the greatest explosion hazard. Methane is explosive between its lower explosive limit (LEL) of $5 \%$ by volume and its upper explosive limit (UEL) of $15 \%$ by volume.

Approximately 50 percent of gas emitted from landfills is methane; carbon dioxide accounts for about 45 percent, and the remainder is composed of nitrogen, oxygen, hydrogen, and other gases [39]. Methane has a global warming potential (GWP) of 21 over a 100-year period [36]. This means that on a kilogram-for-kilogram basis, over a 100-year period, methane is 21 times more potent than carbon dioxide in causing climate change.

The levels of methane in the study area ranged between $2310 \mathrm{ppm}$ and $2771 \mathrm{ppm}$ which shows that the molecules present in the atmosphere were more than 2 times the regulatory limit of $1000 \mathrm{ppm}$ [33]. The Occupational Safety and Health Administration (OSHA) has no permissible exposure limit for methane, but the National Institute for Occupational Safety and Health's (NIOSH) maximum recommended safe methane concentration for workers during an 8-hour period is $1000 \mathrm{ppm}$ (0.1 percent). Methane is considered an asphyxiant at extremely high concentrations of 500,000 ppm and can displace oxygen in the blood at a concentration of 1000 ppm.

Hydrogen sulphide $\left(\mathrm{H}_{2} \mathrm{~S}\right)$ is the most common sulphides responsible for landfill odours. The gas produces a very strong rotten-egg smell even at very low concentrations. It is the most emitted from landfills at the highest rates and concentrations. Humans are extremely sensitive to hydrogen sulphide odours and can smell such odors at concentrations as low as 0.5 to $1 \mathrm{ppb}$. At levels approaching $50 \mathrm{ppb}$, people can find the odor offensive. Average concentrations in ambient air range from 0.11 to $0.33 \mathrm{ppb}$ [40].

Hdrogen sulphide is flammable with is lower explosive limits of $4 \%$ and its upper explosive limit is $44 \%$ and it can pose as an explosion hazard. Within the vincity of dump site fires $\mathrm{H}_{2} \mathrm{~S}$ concentration ranges from 3.4 to 7.7 ppm. Reported readings are below regulatory of $10 \mathrm{ppm}$ [33]. According to information collected by the Connecticut Department of Health, the concentration of hydrogen sulphide in ambient air around a landfill is 
usually close to $15 \mathrm{ppb}[40]$.

\section{Conclusion}

Municipal solid waste open dump site operation is an important element of waste management in Nigeria, both today and in the future. Dump site fires are common occurrences in the study area. When they do occur, however, they tend to attract a great deal of public attention and challenge the fire service. Dump site fires in the study area could threaten the health of anyone especially the dump site workers that are regularly exposed to the thick smoke. This study suggests that exposure to chemicals and other substances emitted from dump site fires is high especially, suspended particulate matter, carbon dioxide, carbon monoxide and is likely to present a significant risk to human health. There is also a need to develop better practices with regard to municipal solid waste open dump site operation and emission control.

\section{References}

[1] Dockery, D.W. and Pope, C.A. (1994) Acute Respiratory Effects of Particulate Air Pollution. Annual Review of Public Health, 15, 107-132. http://dx.doi.org/10.1146/annurev.pu.15.050194.000543

[2] US EPA (1999) National Emission Standards for Hazardous Air Pollutants for Source Categories. Cement Manufacturing Industries Federal Register, 64, 113.

[3] Jeff, G. and Hans, P. (2004) Assessment of Environmental Impact of the Holcim Cement—Dundee Plant. Ecology Centre.

[4] Clean Air (2207) Revisions to the National Ambient Air Quality Standards for Particle Matter. Federal Register, 62, 38651-38970.

[5] Pope, C.A., et al. (2002) Lung Cancer, Cardiopulmonary Mortality, and Long-Term Exposure to Fine Particulate Air Pollution. Journal of the American Medical Association, 287, 1132-1141. http://dx.doi.org/10.1001/jama.287.9.1132

[6] Sanjay, R. (2008) Exposure to Bad Air Raises Blood Pressure, Study Shows, Science Daily. Ohio State University, Columbus.

[7] Pope, C.A. (1995) Respiratory Health Effects of Passive Smoking in Cancer and Other Disorders. Archives of Environmental Health, 46, 90-96. http://dx.doi.org/10.1080/00039896.1991.9937434

[8] Laden, F., Neas, L.M., Dockery, D.W. and Schwartz, J. (2000) Association of Fine Particulate Matter from Different Sources with Daily Mortality in Six US Cities. Environmental Health Perspectives, 108, 941-947. http://dx.doi.org/10.1289/ehp.00108941

[9] WHO (World Health Organisation) (2000) Air Quality Guidelines for Europpe. WHO Regional Publication European Series, No. 91. World Health Organisation Regional Office for Europe, Copenhagen.

[10] American Chemical Society (2008) Newly Detected Air Pollutant Mimics Damaging Effects of Cigarette Smoke. Science Daily, American Chemical Society, Washington DC.

[11] Knox, G. (2008) Atmospheric Pollutants and Mortalities in English Local Authority Areas. Journal of Epidemiology \& Community Health, 62, 442-447. http://dx.doi.org/10.1136/jech.2007.065862

[12] Boubel, R.W., Fox, D.L., Turner, D.B. and Stern, A.C. (1994) Effects on Materials and Structures, Fundamentals of Air Pollution. 3rd Edition, Academic Press, New York.

[13] Bates, M. (2004) Managing Landfill Sites Fires in Northampton. Report, Environment and Transport Scrutiny Committee. Northamptonshire, County Council, Northampton, Northamptonshire.

[14] Fisher, C. (1999) Gas Emission from Landfills: An Overview of Issues and Research Needs Survey. ECONS SA Environmental Report, Swedish Environmental Protection Agency, Stockholm.

[15] Ettala, M., Rahkonen, P., Rossi, E., Mangs, J. and Keski-Rahkonen, O. (1996) Landfill Fires in Finland. Waste Management \& Research, 14, 377-384. http://dx.doi.org/10.1177/0734242X9601400405

[16] Bogner, J. and Scott, P. (2001) Landfill $\mathrm{CH}_{4}$ Emissions: Guidance for Field Measurements. In: Lagerkvist, A., Ed., 1992-1994 IEA Landfill Gas Activity, Report No 97:01, Luleå University of Technology, Luleå, 29-46.

[17] Ruokojarvi, P., Ruuskanen, J. and Ettala, M. (1997) Landfill Fires and Emissions of Toxic Organic Compounds. Environmental Impact, Aftercare and Remediation of Landfills, CISA, Cagliari, 4, 151-154.

[18] Roots, O., Henkelmann, B. and Schramm, K.W. (2004) Concentrations of Polychlorinated Dibenzo-p-Dioxins and Polychlorinated Dibenzofurans in Soil in the Vicinity of a Landfill. Chemosphere, 57, 337-342. http://dx.doi.org/10.1016/j.chemosphere.2004.06.012

[19] Lemieux, P.M., Lutes, C.C. and Santoianni, D.A. (2004) Emissions of Organic Air Toxics from Open Burning: A 
Comprehensive Review. Progress in Energy and Combustion Science, 30, 1-32. http://dx.doi.org/10.1016/j.pecs.2003.08.001

[20] Dyke, P.H., Foan, C., Wenborn, M. and Coleman, P.J. (1997) A Review of Dioxin Releases to Land and Water in the UK. Science of the Total Environment, 207, 119-131. http://dx.doi.org/10.1016/S0048-9697(97)00254-4

[21] FEMA (2002) Landfill Fires Their Magnitude, Characteristics and Mitigation. United States Fire Administration, National Fire Data Center, FA-225, Arlington, Virginia.

[22] NDES: Nigeria Delta Environment Survey (2003) Report on the Niger Delta Environment 1. 9-14.

[23] Akpokodje, E.G. (1987) The Engineering Geological Characteristics and Classification of the Major Superficial Soils of the Niger Delta. Engineering Geology, 23, 193-211. http://dx.doi.org/10.1016/0013-7952(87)90090-1

[24] Allen, J.R.L. (1965) Late Quaternary Niger Delta and Adjacent Areas. AAPG Bulletin, 49, 547-600.

[25] Darefaka, M.D. (2003) Water Quality Standards and Guidelines in Nigeria. 2nd Earthwatch Conference on Water, Port Harcourt, 26 August 2003, 3-11.

[26] Gobo, A.E. (1998) Meteorology and Man’s Environment. African-Link Books, Ibadan, 21-23.

[27] Okoko, K.A.B. and Nna, J.N. (1998) Emerging Trends and Community Perception in the Nigerian Oil Industry. Nigerian Journal of Oil and Politics, 1, 44-54.

[28] Ajugwo, A.O. (2013) Negative Effects of Gas Flaring: The Nigerian Experience. Journal of Environment Pollution and Human Health, 1, 6-8.

[29] American Public Works Association (APWA) (1975) Solid Waste Collection Practices. Public Administration Service, Chicago.

[30] NDDC: Niger Delta Development Commission (2004) Environmental Situation in the Niger Delta Area. NDDC, Port Harcourt.

[31] Lewicki, R. (1999) Early Detection and Prevention of Landfill Fires. International Waste Management and Landfill Symposium, Sardinia 99, Cagliari, 4-8 October 1999, 613-620.

[32] Federal Environmental Protection Agency: FEPA (1995) Nigerian Ambient Air Quality Standard.

[33] NIOSH (National Institute for Occupational Safety and Health) (1977) Criteria for a Recommended StandardHydrogen Sulfide. US Department of Health and Human Services, Public Health Service, Washington DC, NIOSH Publ No 77-158.

[34] United Kingdom Air Quality: (UKAQ) (2005) Report on 2005 Air Pollution Study in United Kingdom. http://www.airquality.co.uk

[35] Nammari, D.R., Hogland, W., Marques, M., Nimmermark, S. and Moutavtchi, V. (2004) Emissions from a Controlled Fire in Municipal Solid Waste Bales. Waste Management, 24, 9-18. http://dx.doi.org/10.1016/j.wasman.2003.08.003

[36] Gribben, J. (1986) Temperature Rise in Global Green House. New Scientist, 15, 31-32.

[37] Börjesson, G. and Svensson, B.H. (1993) Interactions between Methane Oxidation and the Formation of $\mathrm{N}_{2} \mathrm{O}$ in a Landfill Cover Soil. 4th International Landfill Symposium Proceedings, 1, 729-733.

[38] Beever, P.F. (1989) Subterranean Fires in the UK—The Problem. Building Research Establishment Information IP3/89, 1-3.

[39] Bogner, J. and Spokas, K. (1996) Field Measurement of Methane and NMOC Emissions: Sources, Sinks and Implications for Emission Modelling. 19th Annual Landfill Gas Symposium, Research Triangle Park, 19-21 March 1996, 189-199.

[40] ATSDR (1999) Toxicological Profile for Hydrogen Sulfide. US Department of Health and Human Services, Public Health Service, Agency for Toxic Substances and Disease Registry, Atlanta. 
Scientific Research Publishing (SCIRP) is one of the largest Open Access journal publishers. It is currently publishing more than 200 open access, online, peer-reviewed journals covering a wide range of academic disciplines. SCIRP serves the worldwide academic communities and contributes to the progress and application of science with its publication.

Other selected journals from SCIRP are listed as below. Submit your manuscript to us via either submit@scirp.org or Online Submission Portal.
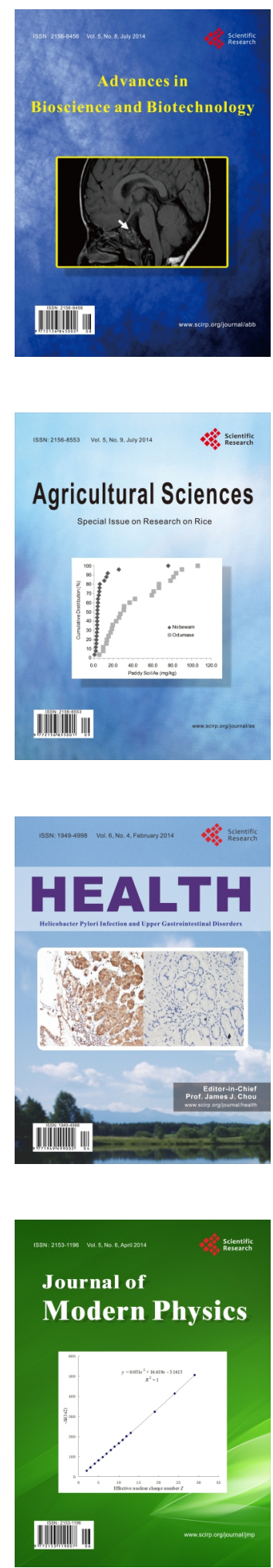
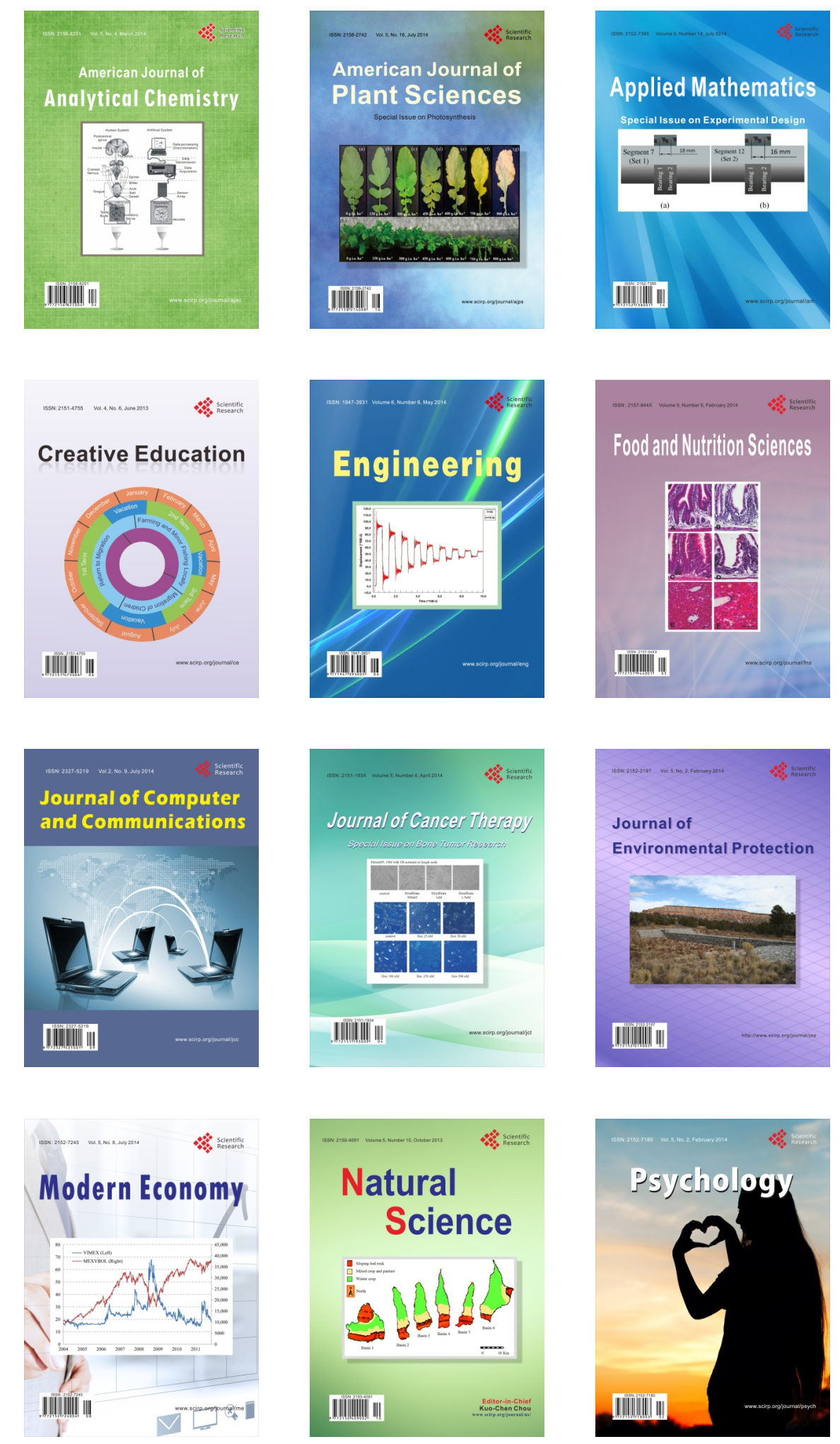